\title{
Factors Affecting E-Rosette Forming Ability in Peripheral Lymphocytes of Insulin Dependent Diabetics
}

\author{
R. Cattaneo, V. Saibene, D. Pescatori, A. Mersi, and G. Pozza \\ Institute of Clinical Medicine, University of Milan, Ospedale San Raffaele, Milan, Italy
}

Summary. Poorly controlled insulin dependent diabetics showed impaired E-rosette forming ability compared to sex and age matched normal controls $(34.8 \pm 3.1, \mathrm{n}=31$ vs $55.5 \pm 1.7, \mathrm{n}=33 ; \mathrm{p}<$ 0.001 ; mean \pm SEM). The reduction of E-rosette cells \% was not related to the duration of diabetes, nor to fasting blood glucose levels. Incubation of lymphocytes from a subsequent series of 17 insulindependent diabetics with insulin $(100 \mu \mathrm{U} / \mathrm{ml})$ plus glucose $(100 \mathrm{mg} / 100 \mathrm{ml})$ significantly increased $\mathrm{E}$ rosette formation $(37.6 \pm 3.3$ vs $47.0 \pm 2.2 ; \mathrm{p}=$ $0.01)$; conversely glucagon $(0.1 \mu \mathrm{g} / \mathrm{ml})$ significantly impaired E-rosette forming ability of normal lymphocytes $(51.5 \pm 3.6$ vs $44.5 \pm 4.2 ; \mathrm{n}=17 ; \mathrm{p}<$ $0.01)$. No difference was observed in cAMP content of normal and diabetic lymphocytes, nor was Erosette forming ability related to intracellular cAMP content. Incubation with increasing glucose concentrations (up to $500 \mathrm{mg} / 100 \mathrm{ml}$ ) did not affect Erosette forming ability of normal lymphocytes. Incubation of normal lymphocytes with diluted $(1: 10)$ serum from sex and age matched insulin dependent diabetics impaired E-rosette forming ability to the level found in diabetics $(61.1 \pm 2.9$ vs $39.7 \pm 4.4 ; p$ $<0.001)$. The results of these in vitro experiments show that insulin and glucagon exhibit opposite effects on E-rosette forming ability and that undefined factor(s) present in diabetic serum may affect this T-cell function.

Key words: T-lymphocytes, E-rosette test, insulin, glucagon, cell mediated immunity, immunity and diabetes, insulin dependent diabetes.

Immunological factors may play an important role in the pathogenesis of insulin dependent diabetes (IDD).
This has been previously suggested by the finding of insulitis [1] and by the observation of organ specific auto-antibodies and of clinical associations between insulin dependent diabetes and autoimmune diseases $[2,3,4]$. This was recently clearly confirmed by the demonstration of specific humoral and cell mediated immune reactions against pancreatic antigens $[5,6,7]$.

The most impressive data arise from studies on islet cell autoantibodies (ICAs), which have been detected in up to $90 \%$ of patients in the earliest phases of the disease [8].

As to cell mediated immunity, there are reports of T-cell defects, manifested by low counts of $\mathrm{E}$ rosette forming cells $[9,10,11,12,13]$ and impaired in vitro response to T-cell mitogens $[14,15]$.

The present study was designed to investigate which factors may be of relevance for T-cell impairment in IDD.

\section{Patients and Methods}

Sixty-one insulin dependent diabetics, fifty-three admitted to hospital because of unsatisfactory metabolic control and eight because of newly discovered diabetes ( 29 males and 32 females), age range 14 to 46 years (mean age 25 years), were included in the study. The duration of the disease ranged between 0 and 20 years (mean 6.2 ); all patients were under $105 \%$ of ideal body weight.

Patients were treated by 2-3 daily injections of short and/or intermediate acting insulins (Actrapid or Semilente MC - Novo Industri A/S - Copenhagen, Denmark); subjects known to suffer from immunologic diseases or receiving drugs known to interfere with cell mediated immunity were excluded.

Poor metabolic control was assumed when fasting blood glucose exceeded $200 \mathrm{mg} / 100 \mathrm{ml}$ and severe glycosuria (> $>10 \mathrm{~g}$ daily) and/or ketonuria were present for at least one of the three days preceding the study.

Sixty-eight healthy non-obese volunteers $(<110 \%$ of ideal body weight), 37 males and 31 females, age range 17 to 48 years, (mean age 27 years), without a family history of diabetes formed the control group. 


\section{Preparation of Lymphocyte Suspensions}

Heparinized venous blood samples $(8 \mathrm{mi})$ were collected after an overnight fast: the latest short-acting insulin injection was administered 12-14 hours before blood sampling. Lymphocytes were separated by density centrifugation on a Ficoll-Hypaque gradient (Lymphoprep-Nyegaard and Co., Oslo) [16]. Macrophages were removed after iron powder phagocytosis, and a suspension containing more than $95 \%$ of lymphocytes with greater than $98 \%$ viability by Trypan Blue exclusion was obtained.

Lymphocytes were adjusted to $3 \times 10^{6}$ cells $/ \mathrm{ml}$ employing, according to experimental purposes (see below), two different media: 1) RPMI-1640 plus $20 \mathrm{mmol}$ Hepes (N-2-Hydroxyethylpiperazine- $\mathrm{N}^{\prime}$-2-ethanesulfonic acid; $\mathrm{Na}$ salt), $\mathrm{pH}$ 7.2-7.4, $290 \mathrm{mosm} / \mathrm{kg}$ (Eurobio, Paris), a 'rich' medium containing glucose $200 \mathrm{mg} / 100 \mathrm{ml}$, aminoacids, vitamins and salts [17]; 2) phosphate-

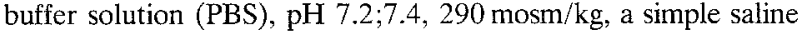
medium (Eurobio, Paris).

\section{E-Rosette Test}

The E-rosette forming technique of Jondal et al. [18] was employed with minor modifications. Fresh sheep erythrocytes, supplied in Alsever's solution, were adjusted after three washings in PBS to $90 \times 10^{6}$ cells $/ \mathrm{ml}$. Aliquots of $0.5 \mathrm{ml}$ were added to $0.5 \mathrm{ml}$ of lymphocyte suspensions $\left(3 \times 10^{6} \mathrm{cells} / \mathrm{ml}\right)$ : the mixture was left $5 \mathrm{~min}$ at room temperature in an atmosphere of $\mathrm{O}_{2}(95 \%)$ and $\mathrm{CO}_{2}(5 \%)$ and then centrifuged at $200 \times \mathrm{g}$ for $5 \mathrm{~min}$. The samples were incubated for 2 hours at $0-2^{\circ} \mathrm{C}$; after this period the pellets were gently resuspended and rosettes (a lymphocyte surrounded by three or more red cells) were counted by microscopic examination of 200 cells in a haemacytometer.

To prevent bias, the operator was unaware of the origin of the sample under examination.

\section{Insulin, Glucagon and Glucose Effect on E-Rosette Forming Ability}

Lymphocyte suspensions in PBS, obtained from normal and/or diabetic subjects (see section 'Results'), were incubated before performing the E-rosette test for $60 \mathrm{~min}$ at $37^{\circ} \mathrm{C}$ in the following conditions:

a) PBS alone or with added glucose $(100-300$ or $500 \mathrm{mg} /$ $100 \mathrm{ml}$ );

b) PBS plus Insulin (Actrapid MC, Novo Terapeutisk Laboratorium, Copenhagen), to a final concentration of $100 \mu \mathrm{U} /$ $\mathrm{ml}$, with or without glucose $100 \mathrm{mg} / 100 \mathrm{ml}$;

c) PBS plus Glucagon (Novo Industri $\mathrm{A} / \mathrm{S}$, Copenhagen), to a final concentration of $0.1 \mu \mathrm{g} / \mathrm{ml}$.

\section{Serum Effect on E-Rosette Forming Ability}

Before performing the E-rosette test, lymphocytes from pairs of normal/diabetic subjects were incubated for $60 \mathrm{~min}$ at $37^{\circ} \mathrm{C}$ in PBS with their own or partner's serum diluted 1:10 with PBS.

\section{cAMP Content of Lymphocytes}

Lymphocytes from normal subjects and diabetic patients were washed three times in Earle saline solution [19], by a $400 \times \mathrm{g}$ for $10 \mathrm{~min}$ centrifugation. Suspensions were adjusted to $5 \times 10^{6} \mathrm{cells} /$ $\mathrm{ml}$ in $50 \mathrm{mmol} / \mathrm{l}$ tris- $\mathrm{HCl}, 4 \mathrm{mmol} / 1 \mathrm{EDTA}, \mathrm{pH} 7.5$; the tubes were exposed to liquid $\mathrm{N}_{2}$ for $3 \mathrm{~min}$ and then incubated at $100^{\circ} \mathrm{C}$ for $3 \mathrm{~min}$. Coagulated proteins were removed by $1500 \times \mathrm{g}$ centrifugation at $4^{\circ} \mathrm{C}$ for $5 \mathrm{~min}$.
The cAMP content of the supernatant was detected by the Gilman procedure [20], employing a binding protein isolated from bovine skeletal muscle [21]. Duplicate cAMP measurements were performed for each lymphocyte sample (cAMP assay kit; TRK 432, The Radiochemical Centre, Amersham); intra-assay CV was $<9 \%$, interassay $\mathrm{CV}<12 \%$; values were expressed as $\mathrm{pmol} / 10^{7}$ cells.

For statistical analysis the two tailed Student $t$ tests for paired or unpaired data and the coefficient of correlation were employed as appropriate. Values are presented as mean \pm SEM

\section{Results}

\section{E-Rosette Forming Ability in Insulin Dependent Diabetics}

Lymphocytes from 31 IDD (aged between 12 and 44 years, mean 23 years) with duration of the disease between 0 and 20 years (mean 7 years) were processed for E-rosette forming ability in RPMI 1640 Hepes as previously described.

The percentage of E-rosette forming cells was significantly lower than in 33 sex and age matched subjects $(34.8 \pm 3.1$ vs $55.5 \pm 1.7$, mean \pm SEM; $p$ $<0.001)$. No sex difference was found in the diabetic group $(12$ males $=35.3 \pm 5.4 ; 19$ females $=34.5 \pm$ 3.8 ), nor were significant correlations observed between E-rosette forming ability and duration of diabetes $(r=0.06)$ or blood glucose concentration (range $64-390, r=0.13$ ). The percentage of $\mathrm{E}$ rosette forming cells was not significantly different between poorly controlled diabetics $(\mathrm{n}=21)$, compared to moderately controlled patients $(\mathrm{n}=10)$ $(33.1 \pm 4.2$ vs $38.3 \pm 3.6)$.

Table 1. Effects of glucose, insulin and glucagon on E-rosette forming ability of lymphocytes from insulin-dependent diabetics (IDD). Upper part: in vitro effect of insulin $(100 \mu \mathrm{U} / \mathrm{ml})$ and insulin $(100 \mu \mathrm{U} / \mathrm{ml})$ plus glucose $(100 \mathrm{mg} / 100 \mathrm{ml})$. Lower part: in vitro effect of glucagon $(0.1 \mu \mathrm{g} / \mathrm{ml})$. Incubations for $60 \mathrm{~min}$ at $37^{\circ} \mathrm{C}$ before performing the E-rosette test. Results are expressed as mean $\pm \mathrm{SEM}$; number of subjects in parentheses

\begin{tabular}{lll}
\hline & & $\begin{array}{l}\text { Lymphocyte E-rosetting } \\
\%\end{array}$ \\
\hline IDD [17] & Basal & $37.6 \pm 3.3$ \\
& Plus insulin & $44.2 \pm 3.3 \quad$ NS \\
& Plus insulin & $47.0 \pm 2.2^{\mathrm{a}}$ \\
& and glucose & $47.0 .5 \pm 3.6^{\mathrm{b}}$ \\
Normal subjects & Basal & $51.5 \pm 4.2^{\mathrm{c}}$ \\
\hline 17$]$ & Plus glucagon & $44.5 \pm 1$ \\
\hline
\end{tabular}

$\mathrm{a}=\mathrm{p}<0.01$ vs basal of IDD

$\mathrm{b}=\mathrm{p}<0.02$ vs basal of IDD

$c=p<0.01$ vs basal of normal subjects

$\mathrm{NS}=$ not significant 


\section{In Vitro Effect of Insulin, Glucagon and Glucose}

The insulin effect on E-rosette forming ability was investigated in a further 17 poorly controlled IDD, 11 males and 6 females, aged from 14 to 46 years (mean 28), with duration of the disease between 0 and 20 years, (mean 6). As shown in Table 1, insulin $(100 \mu \mathrm{U} / \mathrm{ml})$ plus glucose $(100 \mathrm{mg} / \mathrm{ml})$ induced a significant increase in E-rosette forming ability of diabetic lymphocytes: insulin alone, however, did not cause a significant increase. The glucagon effect on E-rosette forming ability was studied in 17 normal volunteers ( 10 males and 7 females, aged between 25 and 37 years, mean 31$)$. Glucagon $(0.1 \mu \mathrm{g} / \mathrm{ml})$ significantly impaired the E-rosette forming ability of normal lymphocytes (Table 1 ).

The effect of glucose was studied in 11 normal subjects ( 7 males and 6 females, aged between 18 and 40 years, mean 29): concentrations of up to $500 \mathrm{mg} / 100 \mathrm{ml}$ did not produce any significant inhibition of the E-rosette forming ability of normal lymphocytes (Table 2).

\section{Effect of Normal and Diabetic Sera}

Lymphocytes from 11 normal/diabetic pairs, matched for sex and age ( 5 males and 6 females, aged between 17 and 32 years, mean 23, with duration of diabetes between 1 and 12 years, mean 6), were incubated with their own or normal partner's serum before performing the E-rosette test.

Diabetic sera caused a striking fall in E-rosette forming ability of normal lymphocytes (Table 3), reaching levels similar to those observed in IDD; conversely normal sera significantly improved Erosette forming ability of diabetic lymphocytes (Table 3).

\section{cAMP Content of Lymphocytes}

There was no correlation between the percentage of E-rosette forming cells and cAMP content of lymphocytes from a group including 11 IDD and 5 normal subjects, nor any difference in cAMP content between normal $(\mathrm{n}=9)$ and diabetic $(\mathrm{n}=10)$ lymphocytes $\left(119 \pm 14\right.$ vs $114 \pm 23 \mathrm{pmol} / 10^{7}$ cells $)$.

\section{Discussion}

The data presented show a significant reduction of peripheral T-lymphocyte percentage in insulin dependent diabetics. These results agree with previous reports from this laboratory $[9,11]$ and with findings from other authors $[10,12,13]$, but differ from
Table 2. Effect of increasing glucose concentrations on E-rosette forming ability of normal subjects. Incubations for $60^{\prime}$ at $37^{\circ} \mathrm{C}$ before performing the E-rosette test. Results are expressed as mean \pm SEM; number of subjects in parentheses

\begin{tabular}{lll}
\hline & $\begin{array}{l}\text { Lymphocyte E-rosetting } \\
\%\end{array}$ \\
\hline $\begin{array}{l}\text { Basal (11) } \\
\text { Glucose }\end{array}$ & $57.9 \pm 3.6$ & \\
$100 \mathrm{mg} / 100 \mathrm{ml}(11)$ & $51.0 \pm 3.2$ & NS \\
$\begin{array}{l}\text { Glucose } \\
300 \mathrm{mg} / 100 \mathrm{ml}(11)\end{array}$ & $50.5 \pm 3.2$ & NS \\
Glucose & $51.1 \pm 3.9$ & NS \\
$500 \mathrm{mg} / 100 \mathrm{ml} \mathrm{(10)}$ & &
\end{tabular}

$\mathrm{NS}=$ not significant

Table 3. Serum effect on E-rosette forming ability. Upper part: effect of normal serum on E-rosette forming ability of lymphocytes from IDD. Lower part: effect of diabetic serum on E-rosette forming ability of lymphocytes from normal subjects. Incubations for $60^{\prime}$ at $37^{\circ} \mathrm{C}$ before performing the E-rosette test. PBS, phosphate buffered saline. For further details see Methods. Results are expressed as mean \pm SEM; number of subjects in parentheses

\begin{tabular}{llll}
\hline & Medium & T\% & $\mathrm{p}$ \\
\hline IDD [11] & PBS & $35.8 \pm 2.5$ & \\
& PBS plus & & $<0.01$ \\
& normal serum & $60.0 \pm 4.0$ & \\
Normal & PBS & $61.1 \pm 2.9$ & \\
subjects (11) & $\begin{array}{l}\text { PBS plus } \\
\text { diabetic serum }\end{array}$ & $39.7 \pm 4.4$ & $<0.001$ \\
\hline
\end{tabular}

those of MacCuish et al. [14] and Hann et al. [22]. The discrepancies may be due both to difference in methods and to heterogeneity among the examined patients.

Technical problems involved in performing the E-rosette test have been reviewed by Aiuti et al. [23]: the presence or absence of proteins in the medium (fetal calf or human serum) seems to be critical. In fact Byrom et al. [24] have recently shown that low counts of peripheral T-cells may be detected in atopic children only when the E-rosette test was performed in the absence of fetal calf serum. In this regard it is noteworthy that MacCuish et al. [14], who did not find a decrease of peripheral T-lymphocytes in IDD, employed fetal calf serum, while we have performed the E-rosette test in its absence. Furthermore we have shown that the addition of diluted normal serum to diabetic lymphocytes may restore a normal E-rosette forming ability. The performance of the E-rosette test in the absence of agents that enhance the stability of the rosettes may disclose a latent impairment of T-cell function in IDD.

A peripheral T-lymphocyte dysfunction in IDD has already been claimed by MacCuish et al. [14] and 
Delespesse et al. [15], who used different tests, such as blastogenesis from vegetable mitogens.

Since the E-rosette forming ability is an active, energy dependent phenomenon, abolished by sodium iodoacetate (an inhibitor of glycolysis) [18], one may argue that the metabolic status of IDD may influence it. So the discrepancy between our results and those of Hann [22], who found normal levels of T-lymphocytes in IDD, may be due to differences in metabolic control of patients. While Hann [22] studied IDD 'under adequate control', the patients of the present study were admitted to hospital because of unsatisfactory diabetic control. Our results show, however, that hyperglycaemia is not related to low counts of $\mathrm{T}$ cells; moreover glucose addition in vitro to normal lymphocytes (up to $500 \mathrm{mg} / 100 \mathrm{ml}$ ) did not impair E-rosette forming ability. In addition, factors such as age at onset or duration of diabetes do not seem related to E-rosette counts of IDD.

Pancreatic hormones show opposite effects in vitro: insulin can restore E-rosette forming ability of diabetic lymphocytes in the presence of glucose, while glucagon exerts an inhibitory effect on normal lymphocytes. These actions may be due to the hormonal modulation of intracellular nucleotides: it is widely recognized that substances inducing a rise of cellular cAMP enhance T-cell function, while agents promoting a rise in intracellular cAMP seem to inhibit E-rosette forming ability [25, 26, 27]. However, we have not been able to show any difference in the cAMP content of normal and diabetic human lymphocytes, in contrast with the reports of increased cAMP content of mononuclear cells from diabetic rats [28].

Even if caution is advisable in extrapolating results of acute in vitro experiments to a chronic in vivo situation, the hypothesis that the hormonal imbalance of IDD (insulin deprivation and glucagon excess) may affect T-lymphocyte function is suggestive. In support of the hypothesis, Fabris and Piantanelli [29] showed that cell mediated immune reactions are strongly depressed in pancreatectomized rats and that daily insulin treatment prevents these experimentally induced immunological alterations.

Finally we have shown that diabetic serum significantly inhibits E-rosette forming ability of normal lymphocytes.

Our observations are in agreement with a previous report from Pallavicini and Nichols [28], who showed a reduction in phytohaemagglutinin induced blastogenesis by alloxan-diabetic rat serum.

Inhibition of $\mathrm{T}$-cell function by serum factors has been described in several pathologic conditions, such as systemic lupus erythematosus [30], Hodgkin's lymphoma [31], infectious mononucleosis [32], mul- tiple sclerosis [33] and pernicious anemia [34]: inhibitory serum factors have been identified as lymphocytotoxic antibodies. The existence of such antibodies in IDD is still unproven.

Acknowledgements. The authors are greatly indebted to Dr. M. A. Brugo (Immunology and Radioimmunology Laboratories, Istituto Sieroterapico Milanese Serafino Belfanti) for cAMP measurement.

Addendum. While this paper was under revision, Selam et al. [35] reported a reduction of E-rosette forming cells in insulin dependent diabetics of recent onset in poor metabolic control. They showed also that metabolic control achieved by the artificial pancreas could rapidly normalise the impaired E-rosette function, suggesting that the T-cell defect may be due to reversible metabolic disturbances.

\section{References}

1. Gepts W (1965) Pathologic anatomy of the pancreas in juvenile diabetes mellitus. Diabetes 14: 619-633

2. Unger B, Stocks A E, Martin FI R, Whittingham S, MacKay I R (1968) Intrinsic factor antibody, parietal cell antibody and latent pernicious anemia in diabetes mellitus. Lancet $\Pi$ : 415-417

3. Irvine W J, Clarke B F, Scarth L, Cullen D R, Duncan L P J (1970) Thyroid and gastric autoimmunity in patients with diabetes mellitus. Lancet U: 163-168

4. Pincon J, David L, Pousset G, François R (1970) Diabetes and Addison's disease association in children. Arch Fr Pediatr 27: 371-376

5. Bottazzo G F, Florin-Christensen A, Doniach D (1974) Isletcell antibodies in diabetes mellitus with autoimmune polyendocrine deficiences. Lancet II: 1279-1283

6. MacCuish A C, Barnes E W, Irvine W J, Duncan L P J (1974) Antibodies to pancreatic islet-cells in insulin-dependent diabetics with coexistent autoimmune disease. Lancet II: $1529-1531$

7. Nerup J, Andersen O O, Bendixen G, Egeberg J, Gunnarson R, Kromann H, Poulsen JE (1974) Cell-mediated immunity in diabetes mellitus. Proc R Soc Med 67: 506-513

8. Bottazzo G F, Doniach D, Pouplard A (1976) Humoral autoimmunity and diabetes mellitus. Acta Endocrinol [Suppl] (Kbh) 205: 55-61

9. Cattaneo R, Saibene V, Pozza G (1976) Peripheral T-lymphocytes in juvenile-onset diabetic (JOD) and in maturity-onset diabetics (MOD). Diabetes 25: 223-226

10. Sakaguchi S, Nakazawa N, Nakamura S, Kono Y, Hazeki H, Kawa A (1976) Cell-mediated immunity in diabetes mellitus. In: Current topics in diabetes research. Excerpta Medica, Amsterdam Oxford, $\mathrm{p} 143$

11. Cattaneo R, Saibene V, Margonato A, Pozza G (1977) In vitro effect of insulin on peripheral T-lymphocyte E-rosette function from normal and diabetic subjects. Boll Ist Sieroter Milan 56: 139-143

12. Kadrnka-Lovrenčić $M$, Rabatić $S$, Mažuran $M$, Oberiter $V$, Dekaris D (1978) Cell-mediated immunity in children with juvenile diabetes mellitus. Diabetologia 15: 224

13. Müller R, Kolb H, Kuschak D, Gries F A, Bertrams J, Jörgens V (1978) Depressed T-cell immunity in juvenile onset diabetics (JOD). Diabetologia 15: 256

14. MacCuish A C, Urbaniak S J, Campbell CJ, Duncan L P J, Irvine W J (1974) Phytohemagglutinin transformation and cir- 
culating lymphocyte subpopulations in insulin-dependent diabetic patients. Diabetes 23: 708-712

15. Delespesse G, Duchateau J, Bastenie P A, Lauvaux J P, Collet H, Govaerts A (1974) Cell-mediated immunity in diabetes mellitus. Clin Exp Immunol 18: 461-467

16. Boyum A (1968) Separation of lymphocytes from blood and bone marrow. Scand J Clin Lab Invest 21 [Suppl 97]: 1-109

17. Moore G E, Gerner R E, Franklin H A (1967) Culture of normal human leukocytes. JAMA 199: 519-524

18. Jondal M, Holm G, Wigzell H (1972) Surface markers on T and $B$ lymphocytes forming nonimmune rosettes with sheep red blood cells. J Exp Med 136: 207-215

19. Earle W R (1944) Production of malignancy in vitro. IV. The mouse fibroblast cultures and changes seen in the living cells. $J$ Natl Cancer Inst 4: 165-212

20. Gilman A G A (1970) A protein binding assay for adenosine 3':5'-cyclic monophosphate. Proc Natl Acad Sci USA 67: 305-312

21. Tovey K, Oldham K G, Whelan J A M (1974) A simple direct assay for cAMP in plasma and other biological samples using an improved competitive protein binding technique. Clin Chim Acta 56: 221-234

22. Hann S, Kaye R, Falkner B (1976) Subpopulations of peripheral lymphocytes in juvenile diabetes. Diabetes 25 : $104-110$

23. Aiuti F, Cerottini J C, Coombs R R A, Cooper H, Dickler HB, Frøland S, Fudemberg H H, Greaves MF, Grey HM, Kunkel G, Natvig J, Preudhomme J L, Rabellino E, Ritts R E, Rowe D S, Seligmann M, Siegal F P, Stjernswärd J, Terry W D, Wybran J (1975) Identification, enumeration and isolation of $\mathrm{B}$ and $\mathrm{T}$ lymphocytes from human peripheral blood. Clin Immunol Immunopathol 3: 584-597

24. Byrom N A, Caballero F, Campbell M A, Chooi M, Lane A M, Hugh-Jones K, Timblin D M, Hobbs J R (1978) T-cell depletion and in vitro thymosin inducibility in asthmatic children. Clin Exp Immunol 31: 490-498

25. Chisari FV, Edington T S (1974) Human T-lymphocyte "E" rosette function. I. A process modulated by intracellular cyclic cAMP. J Exp Med 140: 1122-1126

26. Galant S P, Remo P A (1975) Beta-adrenergic inhibition of human T-lymphocyte rosettes. J Immunol 114: 512-513
27. Prieur A M, Granger A G (1975) The effect of agents which modulate levels of the cyclic nucleotides on human lymphotoxin secretion and activity in vitro. Transplantation 20: 331-337

28. Pallavicini M G, Nichols W K (1976) Inhibition of lymphocyte blastogenesis by factor(s) in alloxan-diabetic rat plasma. Diabetes 25: 614-622

29. Fabris N, Piantanelli L (1977) Differential effect of pancreatectomy on humoral and cell-mediated immune responses. Clin Exp Immunol 28: 315-325

30. Mittal K K, Rossen R D, Sharp J T, Lidsky MD, Butler W T (1970) Lymphocyte cytotoxic antibodies in systemic lupus erythematosus. Nature 225: 1255-1256

31. Grifoni V, Del Giacco GS, Tognella S, Marconi P E, Mantovani G (1970) Lymphocytotoxins in Hodgkin's disease. Ital J Immunol Immunopathol 1: 21-31

32. Mottironi V D, Terasaki P I (1970) Lymphocytotoxins in disease. I. Infectious mononucleosis, rubella and measles. In: Terasaki P I (ed) Histocompatibility testing. Williams and Wilkins Co., Baltimore, p 301-308

33. Kuwert E, Bertrams J (1972) Leucocyte iso and auto-antibodies in multiple sclerosis (MS) with special regards to complement-dependent cold-reactive autolymphocytotoxins (COCOCy). Eur Neurol 7: 65-71

34. Goldberg LS, Cunningham JE, Terasaki P I (1972) Lymphocytotoxins and pernicious anemia. Blood 39: 862-865

35. Selam J L, Clot J, Andary M, Mirouze J (1979) Circulating lymphocyte subpopulations in juvenile insulin-dependent diabetes. Correction of the abnormalities by adequate blood glucose control. Diabetologia 16: 35-40

Received: September 27, 1978, and in revised form: August 7, 1979

Dr. Vincenzo Saibene

Cattedra di Clinica Medica

Ospedale S. Raffaele

I-20090 Milano-Segrate

Italy 